\title{
18. DISTRIBUTION OF FIRST SERIES TRANSITION METALS IN ROCKS RECOVERED DURING DSDP LEG 22 IN THE NORTHEASTERN INDIAN OCEAN ${ }^{1}$
}

\author{
Henri Bougault, Centre Oćeanologique de Bretagne, Brest, France
}

\section{INTRODUCTION}

$\mathrm{Ti}, \mathrm{V}, \mathrm{Cr}, \mathrm{Fe}, \mathrm{Co}, \mathrm{Ni}, \mathrm{Cu}$, and $\mathrm{Zn}$ have been analyzed from Sites $211,213,214,215$, and 216 of DSDP Leg 22 of the Glomar Challenger in the northeastern Indian Ocean. According to these trace elements, three different types of source material are broadly defined: the basin floor basalts with a composition similar to tholeiites from mid-oceanic ridges, the basalts and the differentiated rocks from the Ninetyeast Ridge, and the diabase and amphibolite from Site 211 .

In this paper the notion of stabilization energy in a ligands field is summarized, analytical techniques used are described, and certain conclusions based on the results are presented.

\section{STABILIZATION OF TRANSITION ELEMENTS IN A LIGANDS FIELD}

The elements of transition of the first series differ from each other by the filling of their $3 \mathrm{~d}$ energy levels; $3 \mathrm{~d}$ orbitals of corresponding ions are partially filled. All the $3 d$ orbitals have the same energy, but ions are surrounded by other anions or dipoles and it can be demonstrated that the five $3 \mathrm{~d}$ orbitals must be divided into two types of orbitals: two orbitals "eg" and three orbitals " $t_{2} g$ " possessing different energies (Orgel, 1964). Thus, the energy of an ion of a transition metal is a function of the number of electrons present in each orbital; this energy, which may be a few kilocalories per mole, has an important effect on the geochemical behavior of the transition metals (Burns et al., 1964; Curtis, 1964; Wagner and Mitchel, 1951). The theoretical variations of this stabilization energy related to an octahedric configuration in function of the atomic number is shown in Figure 1.

Allegre et al. (1968) proposed the use of the diagram log (concentration of the element in rock/concentration of the element in chondrite) for the transition elements versus the atomic number of the element, which was commonly used for rare earth studies. An example of the diagram is presented in Figure 2. The effect of the stabilization energy for the different metals is clearly shown (the $W$-shaped plot); the $W$ shape of the diagram is increasingly sharp as the magmatic differentiation is more pronounced.

\section{ANALYTICAL METHODS}

$\mathrm{Ti}$ and $\mathrm{Fe}$ were analyzed by a classic $\mathrm{X}$-ray fluorescence method using a glass disk made of $6 \mathrm{~g}$ of $\mathrm{LiaB}_{4} \mathrm{O}_{7}, 1 \mathrm{~g}$ of $\mathrm{La}_{2} \mathrm{O}_{3}$, and $1 \mathrm{~g}$ of calcinated powdered sample; $\mathrm{G} 2, \mathrm{BCR}$

\footnotetext{
${ }^{1}$ Contribution No. 164 of the Departement Scientifique, Centre Oceanologique de Bretagne.
}

1, PCC 1, DTS 1, PCC 1, and AGR 1 have been used as standards for calibration curves. $\mathrm{Cr}, \mathrm{Ni}$, and Co determinations have been obtained both by $\mathrm{X}$-ray fluorescence using pellets and by atomic absorption. The solutions used for atomic absorption analyses were obtained with $\mathrm{HF}-\mathrm{H}_{2} \mathrm{SO}_{4}$ dissolution of the powdered sample, evaporation to dryness, and dissolution with $50 \mathrm{~cm}^{3}$ of $\mathrm{NC} 1 \mathrm{~N}$. Calibration curves were obtained with solutions containing the same quantities of major elements as found in the rocks. A $\mathrm{C}_{2} \mathrm{H}_{2}-\mathrm{N}_{2} \mathrm{O}$ flame was used for $\mathrm{V}, \mathrm{Cr}, \mathrm{Ni}$, and Co determinations; $\mathrm{C}_{2} \mathrm{H}_{2}$ air flame was used for $\mathrm{Cu}$ and $\mathrm{Zn}$.

\section{RESULTS}

The results of the trace element analyses are shown in Table 1. All concentrations have been expressed in ppm metal; at least two samples per site were analyzed. The two samples of Site 211 represent two different types of rocks; all other results were obtained from two different samples of the same rock type.

The diagram log (concentration of the element in rock/concentration of the element in chondrites) for Site 211 is shown in Figure 3, for Sites 213 and 215 in Figure 4, and for Sites 214 and 216 in Figure 5. All the analyzed rocks plot on a $W$-shaped diagram. The values of element concentrations in chondrite chosen for calculating the ratio are as follows: Ti: $660 ; \mathrm{V}$ : $50 ; \mathrm{Cr}: 2700 ; \mathrm{Mn}$ : $2500 ; \mathrm{Fe}$ : 250,700; Co: 800; Ni: 13400; Cu: 100; Zn: 50.

Two pairs of elements are considered in Figures 6 and 7. The V-Cu pair have low stabilization energy and $\mathrm{Cr}-\mathrm{Ni}$ have a high stabilization energy. The combined effects of the partition coefficients of these elements directly related to their stabilization energy, together with the magmatic differentiation, give a positive correlation between $\mathrm{V}$ and $\mathrm{Cu}$ on one hand and between $\mathrm{Cr}$ and $\mathrm{Ni}$ on the other. The correlation found for these two pairs of elements suggests that the notion of stabilization energy due to ligands field can be applied to magmatic processes.

The behavior and the values of these transition elements leads us to group the different sites as follows: Sites 214 and 216 from the Ninetyeast Ridge, Sites 213 and 215 from the Indian Ocean basin floor, and Site 211 situated $300 \mathrm{~km}$ west of the Java Trench.

Site 211: The sample analyzed from Site 211 , Core 12, Section $1,143-145 \mathrm{~cm}$ is a diabase while the sample from Core 15, Section 2, 0-5 cm is an amphibolite. Except for Ti, the abundances of the considered trace elements are higher in the diabase sill than in the amphibolite; this is very signficiant for $\mathrm{Ni}(127$ and $75 \mathrm{ppm})$ and $\mathrm{Cr}$ (275 and 70 $\mathrm{ppm}$ ). From the partition coefficient data it was suggested (Schwarcz, 1967) that the stabilization energy $\Delta$ is higher for biotite than for hornblende. Since the content of biotite in the diabase sill is higher than that of amphibolite (Chapter 17), it is likely that the abundances of $\mathrm{Cr}$ and $\mathrm{Ni}$ 


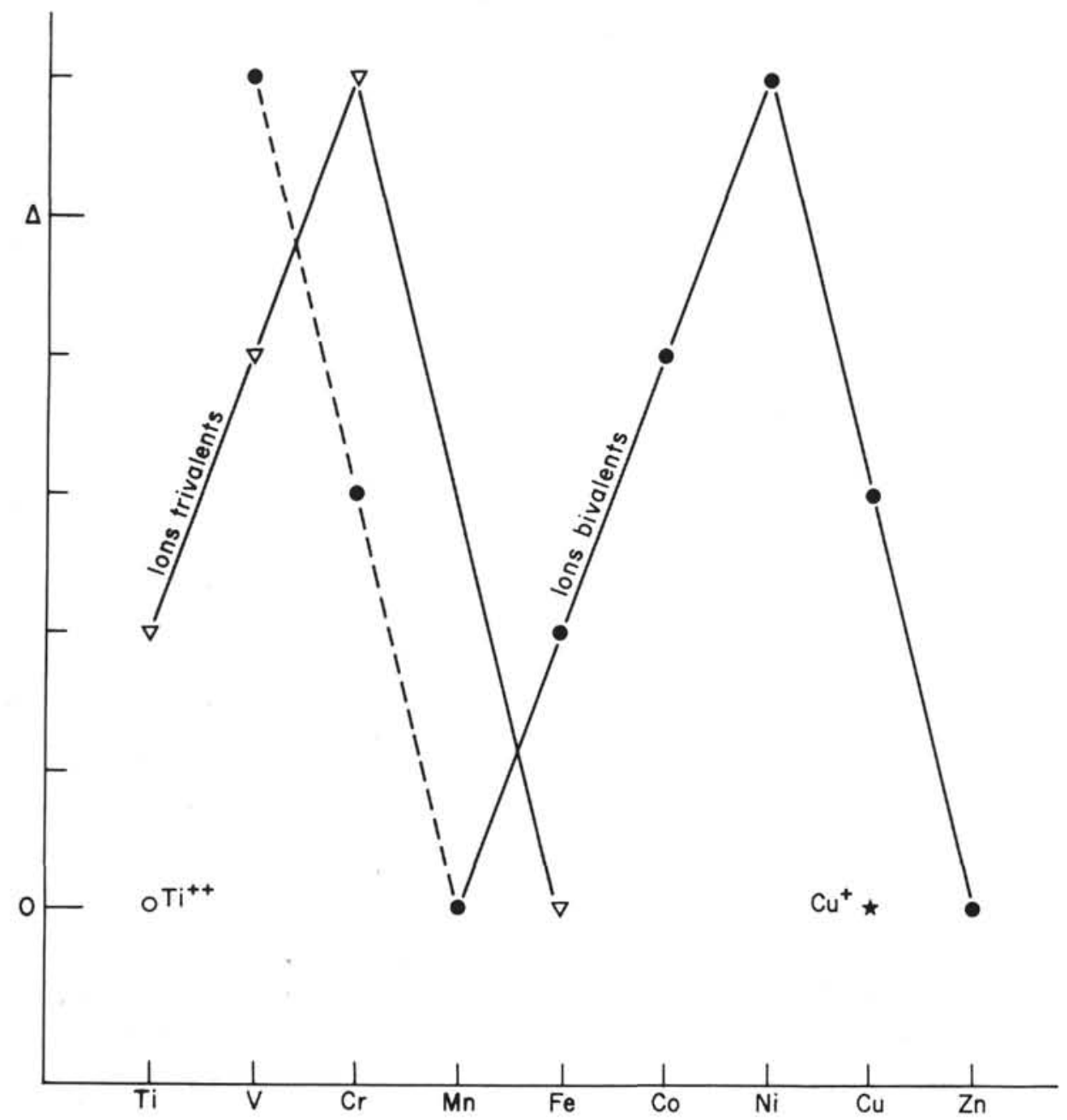

Figure 1. Stabilization energy in an octahedric field.

in these rocks are related to the content of minerals associated with a differentiation process.

Sites 213 and 215: From Site 213 one sample was analyzed from Core 18, Section 1 at $144-150 \mathrm{~cm}$ and one from Section 2, 101-103 cm. From Site 215 one sample was analyzed from Core 18 , Section 2,106-110 cm and one from Core 19, Section 2, $145-150 \mathrm{~cm}$.

Using the McDonald and Katsura (1964) silica versus total alkalis variation diagram, it is observed that these samples from Sites 213 and 215 have very near the Hawaiian tholeiite and alkali basalt division line with an equation of: $Y=0.37 X-14.4\left(X=\mathrm{wt} \% \mathrm{SiO}_{2}\right.$ and $Y=$ wt\% $\mathrm{Na}_{2} \mathrm{O}+\mathrm{K}_{2} \mathrm{O}$ ). Little is known about the distribution of the transitional metals in alkali basalts and tholeiites. From the present data, it is observed that the transition metal distribution in the rocks of these two sites is very close to the mean distribution of mid-oceanic ridge basalts.

Sites 214 and 216: Site 214 contained two types of igneous rocks: a differentiated flow (oceanic andesite, Chapter 17) with an $\mathrm{SiO}_{2}$ content higher than $54 \%$ and a basaltic flow. Basalts from both Sites 214 and 216 have a similar transition metal distribution. Table 1 and Figure 5 show high values of the ratio (element in rock/element in chondrite) for $\mathrm{Ti}-\mathrm{V}$ and for the $\mathrm{Cu}-\mathrm{Zn}$ pairs. The $\mathrm{Ni}-\mathrm{Cr}$ contents are lower than in mid-oceanic ridge basalts. These results suggest that differentiation has given rise to the distribution of the trace elements. There is a high concentration of elements with low stabilization energy and a low concentration of elements with high stabilization energy. It is difficult to classify the basalts from Sites 214 and 216 as tholeiitic or alkali basalts. Nevertheless, the rocks from these two sites on the Ninetyeast Ridge are different from tholeiites of the mid-oceanic ridges as far as the transition metals are concerned:

\begin{tabular}{l|cccccccc} 
& $\mathrm{Ti}$ & $\mathrm{V}$ & $\mathrm{Cr}$ & $\mathrm{Fe}$ & $\mathrm{Co}$ & $\mathrm{Ni}$ & $\mathrm{Cu}$ & $\mathrm{Zn}$ \\
\hline $\begin{array}{l}\text { Ninetyeast } \\
\begin{array}{l}\text { Ridge } \\
\text { Tholeiite }\end{array}\end{array}$ & 13,000 & 420 & 60 & 95,000 & 60 & 45 & 120 & 100 \\
7,000 & 250 & 230 & 81,550 & 60 & 100 & 60 & 60
\end{tabular}

Two samples of differentiated rocks from Site 214 were also analyzed. They are located in Core 48, Section 1, $94-100 \mathrm{~cm}$, from a transition zone, and in Core 49, Section $1,137-144 \mathrm{~cm}$. From a transition metal distribution point of view, they are the most differentiated rocks (Figure 5). The concentrations of $\mathrm{Ni}, \mathrm{Cr}$, and $\mathrm{V}$ are very low (Table 1). 


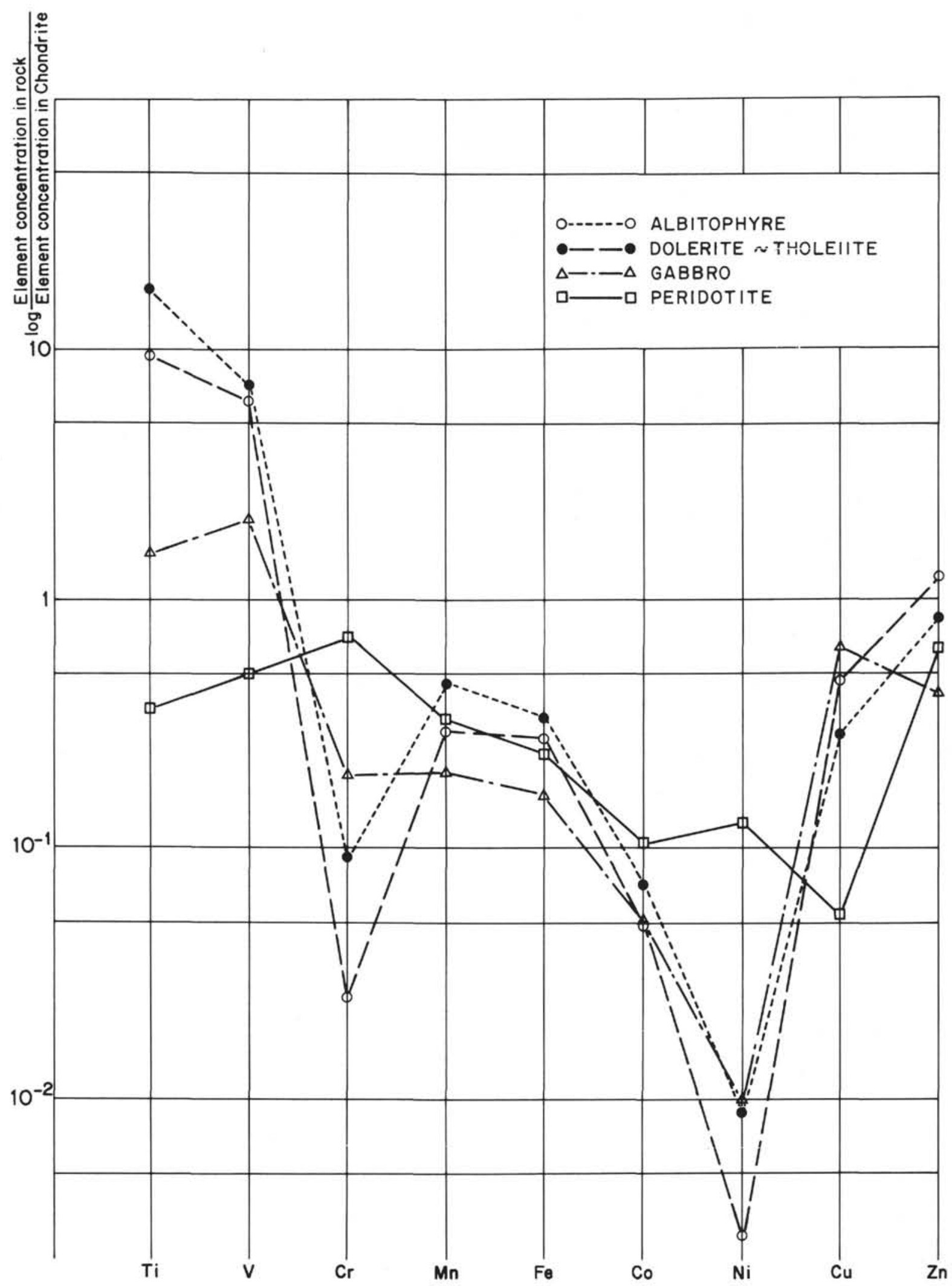

Figure 2. Evolution of the transitional elements in the Pindo amphibolitic suite : chondrite-normed diagram. 
TABLE 1

Transitional Trace Element Analyses of Rocks Recovered from DSDP Leg 22 in the Indian Ocean

\begin{tabular}{llrrrrrrrrl}
\hline Site & \multicolumn{1}{c}{ Sample } & $\mathrm{Ti}$ & $\mathrm{V}$ & $\mathrm{Cr}$ & $\mathrm{Fe}$ & $\mathrm{Co}$ & $\mathrm{Ni}$ & $\mathrm{Cu}$ & $\mathrm{Zn}$ & Rock Type \\
\hline 211 & $211-15-2,0-5$ & 15,100 & 115 & 70 & 63,600 & 36 & 75 & 21 & 70 & Amphibolite \\
& $211-12-1,143-145$ & 13,280 & 140 & 275 & 73,800 & 69 & 127 & 31 & 80 & Diabase \\
\hline 214 & $214-53-1,26-30$ & 12,700 & 390 & 80 & 103,000 & 59 & 55 & 31 & 104 & \\
& $214-53-1,30-35$ & 12,100 & 385 & 75 & 110,000 & 60 & 49 & 111 & 104 & Basalt \\
& $214-53-1,97-100$ & 12,100 & 400 & 77 & 104,700 & 60 & 50 & 110 & 100 & Ninetyeast Ridge \\
& $214-53-1,28-30$ & 13,500 & 420 & 57 & 92,500 & 62 & 39 & 165 & 106 & \\
& $214-54-2,117-127$ & 12,800 & 370 & 62 & 93,000 & 60 & 45 & 153 & 91 & \\
\hline 216 & $216-37-2,80$ & 16,570 & 420 & 50 & 90,700 & 60 & 33 & 147 & 100 & Basalt \\
& $216-38-2,145-150$ & 16,300 & 420 & 50 & 98,900 & 60 & 27 & 122 & 100 & Ninetyeast Ridge \\
\hline 214 & $214-48-1,94-100$ & 8,340 & 38 & 4 & 70,400 & 33 & 10 & 5 & 115 & Differentiated rocks \\
& $214-49-1,137-144$ & 8,760 & 38 & 0 & 68,880 & 44 & 5 & 5 & 115 & Ninetyeast Ridge \\
\hline 213 & $214-18-1,144-150$ & 6,060 & 235 & 280 & 74,000 & 68 & 81 & 80 & 75 & \multirow{2}{*}{ Basalt } \\
& $213-18-2,101-103$ & 6,180 & 235 & 290 & 73,800 & 66 & 85 & 80 & 85 & \\
\hline 215 & $215-18-2,106-110$ & & 200 & 200 & & 50 & 92 & 47 & 55 & \multirow{2}{*}{ Basalt } \\
& $215-19-2,145-150$ & 10,000 & 220 & 200 & 62,300 & 50 & 91 & 75 & 55 & \\
\hline
\end{tabular}

Figure 2, which shows the ratio of the distribution of trace elements in various types of rocks, indicates that the concentrations of $\mathrm{V}$ and $\mathrm{Cu}$ increases from a peridotite to a basalt and then decreases slightly from a basalt to an albitophyre. Similar observations about the behavior of V and $\mathrm{Cu}$ were mentioned by Siedner (1965) for the fractionation of an alkali igneous suite. Although no ultrabasic samples are available from the Indian Ocean sites, the evolution of $\mathrm{V}$ and $\mathrm{Cu}$ can still be observed. The basalts from the Ninetyeast Ridge sites $(214,216)$ with relatively high $\mathrm{V}$ and $\mathrm{Cu}$ content ( 400 and $120 \mathrm{ppm}$, respectively) are more differentiated than those from the basin floor sites $(213,215)$ having a V content of $200 \mathrm{ppm}$ and a $\mathrm{Cu}$ content of $80 \mathrm{ppm}$. The intermediate differentiated rocks from Site 214 have low concentrations of $\mathrm{V}$ and $\mathrm{Cu}$ (38 and $5 \mathrm{ppm}$, respectively).

\section{CONCLUSIONS}

The distribution of the transitional trace elements suggests the following conclusions:

1) The observed difference between the diabase sill and amphibolite from Site 211 is due to the mineralogical differences between these two rocks.

2) The basalts from Sites 213 and 215 situated in the central Indian Basin and in the Wharton Basin on both sides of the Ninetyeast Ridge are similar to mid-oceanic ridge basalts.

3) The basalts from Sites 214 and 216 of the Ninetyeast Ridge are different from tholeiites of mid-oceanic ridges. The differentiated rocks from Site 214 are the most differentiated type of sample studied here as far as the transitional trace elements are concerned.

\section{REFERENCES}

Allegre, C. J., Javoy, M., and Michard, G., 1968. Etude de l'abondance des éléments de transition dans l'écorce terrestre, comparée à celle des terres rares: In Originie et distribution des éléments. Ahrens, L. H. (Ed.). Pergamon Press, p. 914-928.

Burns, R. G., Clark, R. H., and Fyfe, W. S., 1964. Crystal field theory and some geochemical applications: In Chemistry of the earth's crust, Vernadsky Centennial Symp., v. 2, p. 88-106.

Curtis, C. D., 1964. Applications of the crystal-field theory to the inclusion of trace transition elements in minerals during magmatic differentiation: Geochem. Cosmochim. Acta, v. 28 , p. $389-403$.

McDonald, G. A. and Katsura, T., 1964. Chemical composition of Hawaiian lavas: J. Petrol., v. 5, p. 82.

Orgel, L. E., 1964. Chimie des éléments de transition: Dunod Ed., Paris.

Schwarcz, H. P., 1967. The effect of crystal field stabilization of transition metals between metamorphic minerals: Geochim. Cosmochim. Acta, v. 31, p. 503-517.

Siedner, G., 1965. Geochemical features of a strongly fractionated igneous suite: Geochim. Cosmochim. Acta, v. 29 , p. $113-137$.

Wagner, L. R. and Mitchell, R. L., 1951. The distribution of trace elements during strong fractionation of basic magma: A further study of the Skaergaard intrusion, East Greenland: Geochim. Cosmochim. Acta, v. 1, p. 121-208. 


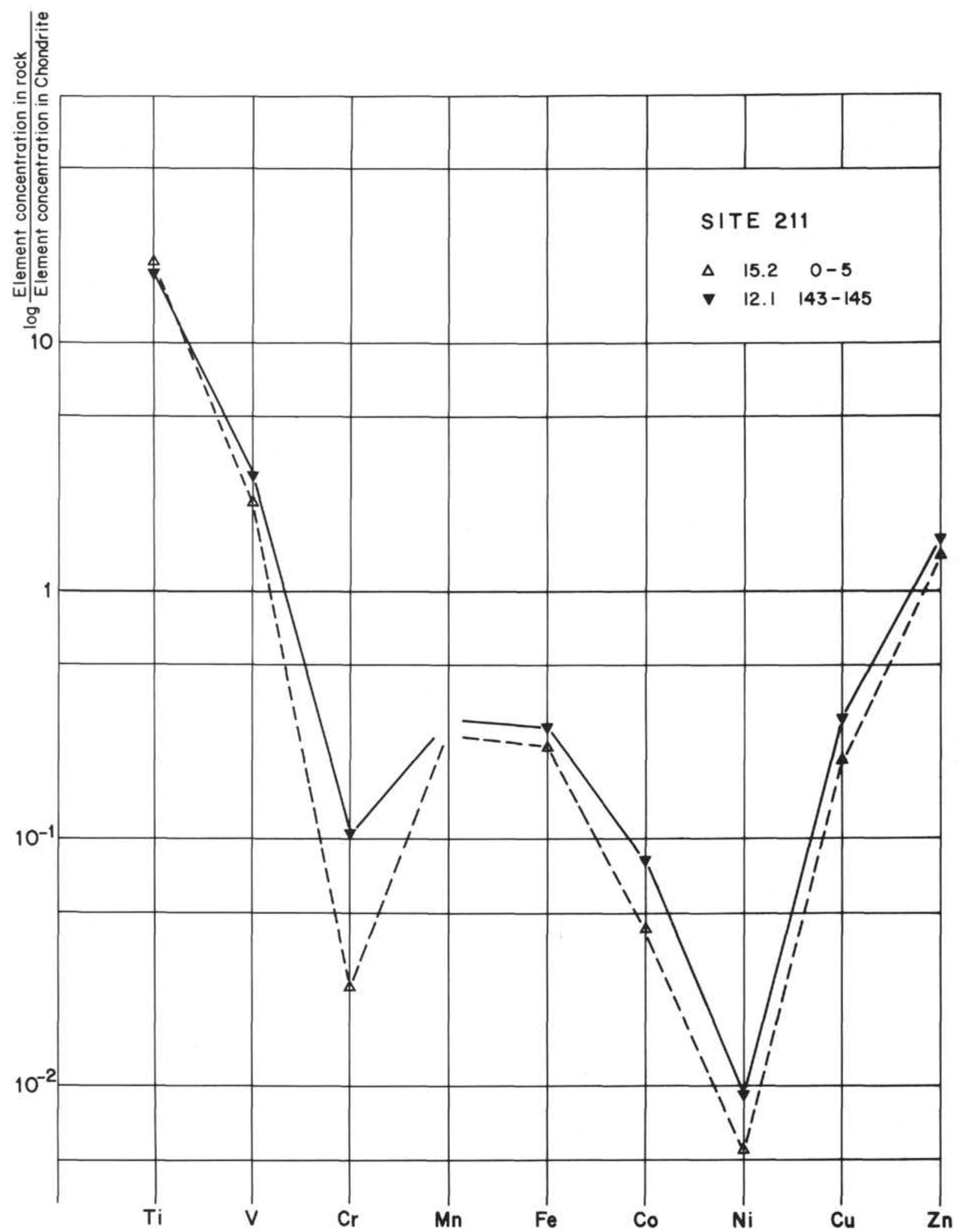

Figure 3. Site 211: chondrite-normed diagram. 


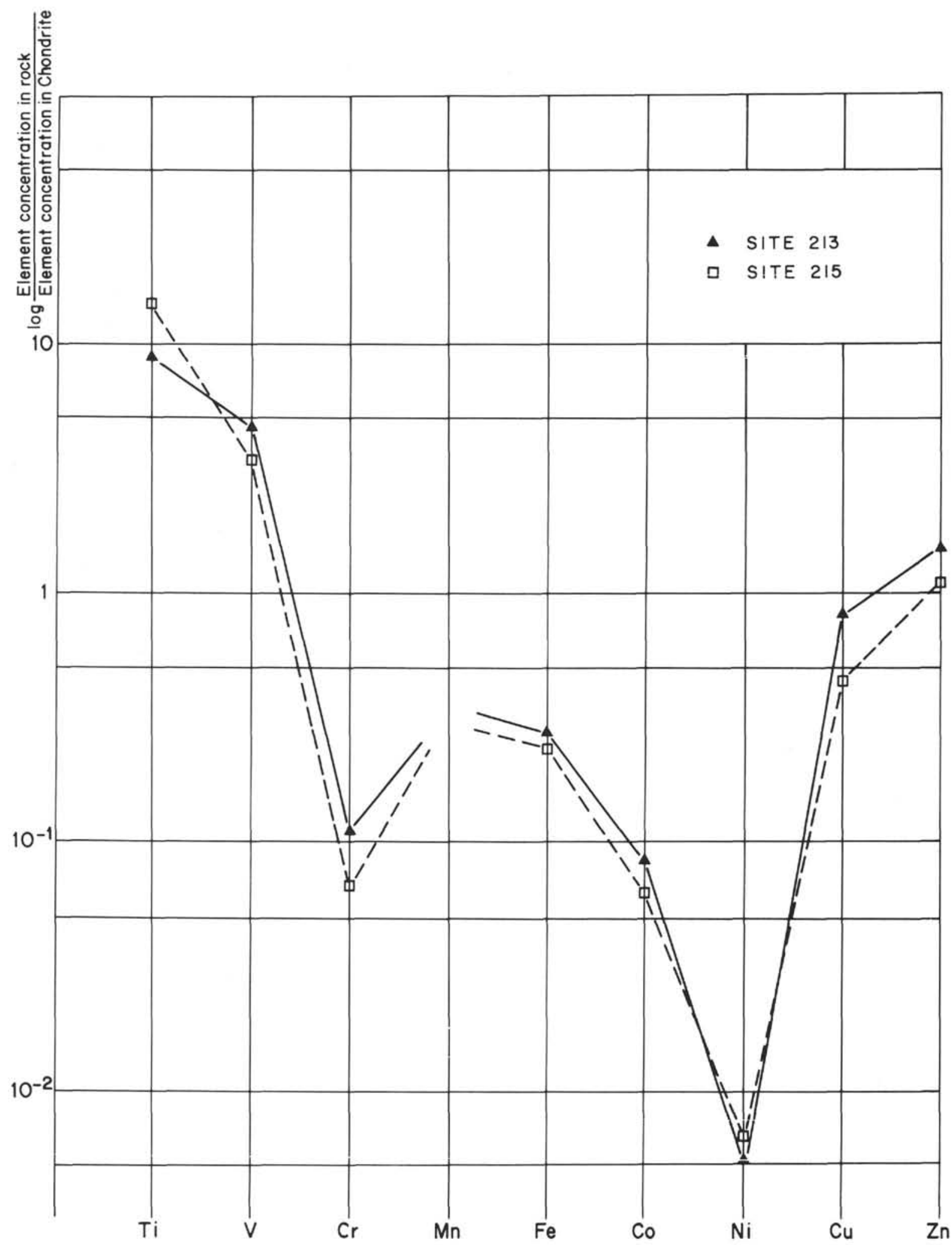

Figure 4. Sites 213 and 215: chondrite-normed diagram. 


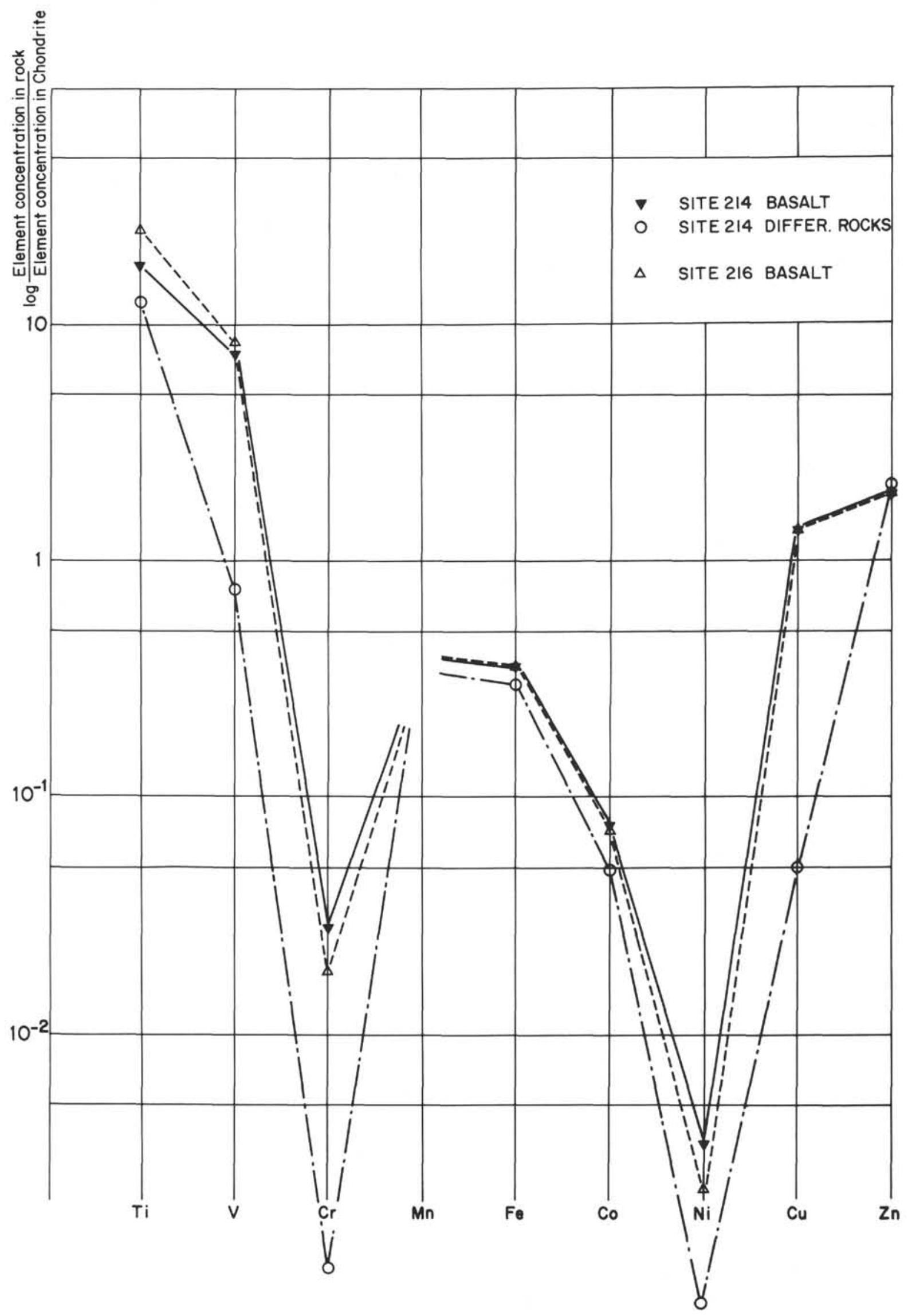

Figure 5. Sites 214 and 216: chondrite-normed diagram. 
H. BOUGAULT

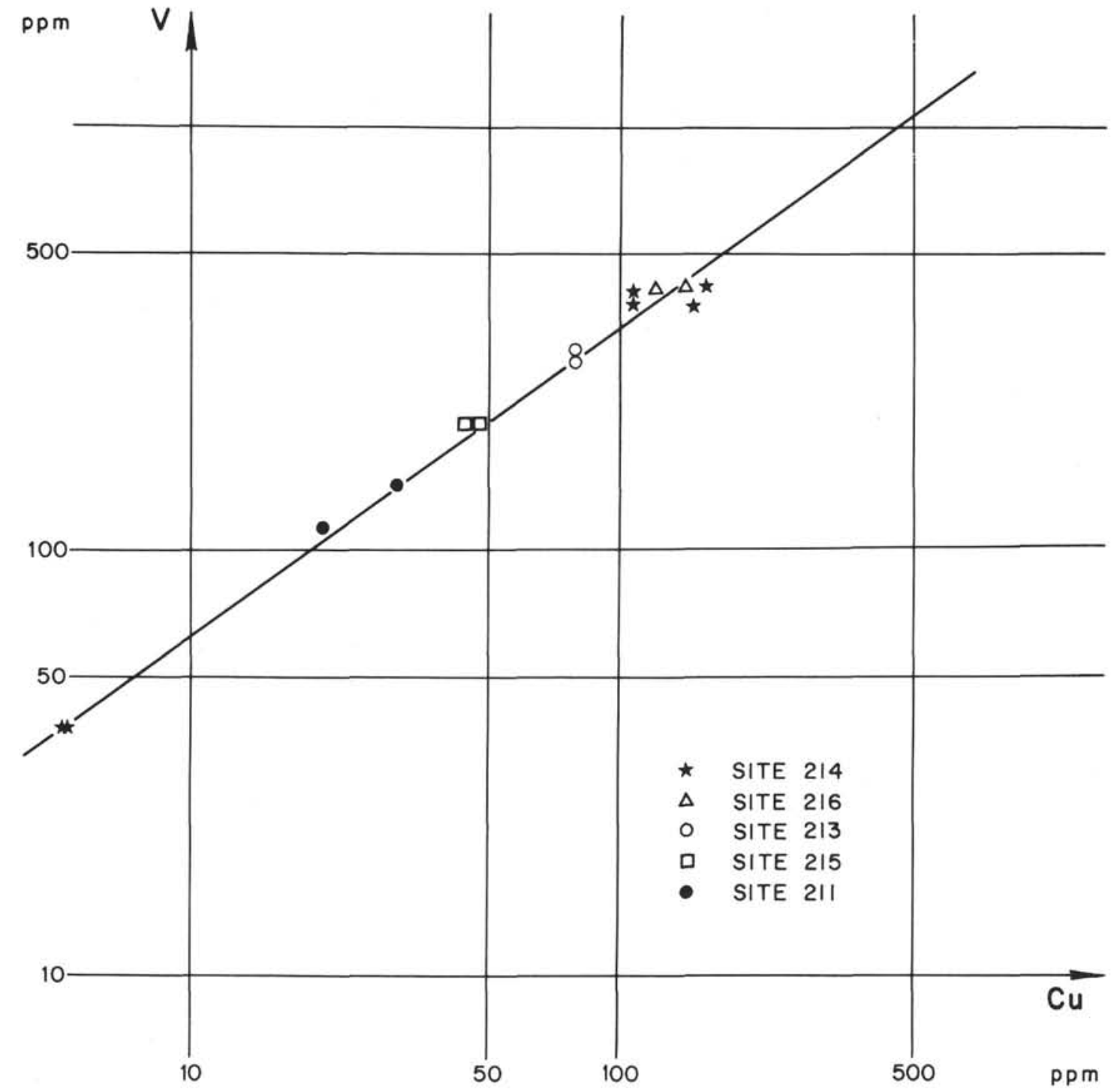

Figure 6. V-Cu correlation, diagram of two elements with low stabilization energy. 


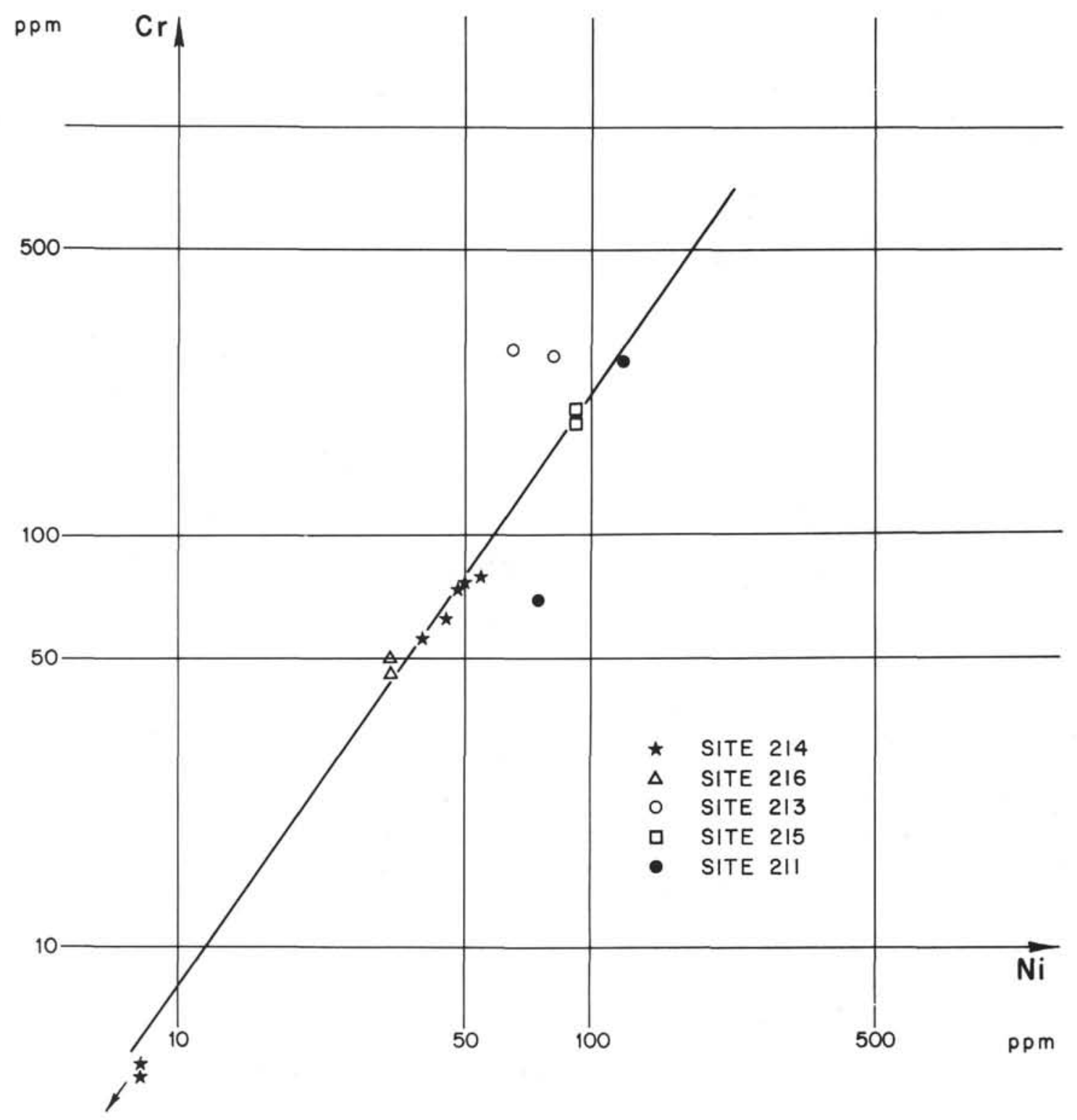

Figure 7. Cr-Ni correlation, diagram of two elements with high stabilization energy. 